\title{
Use of CuNi/YSZ and CuNi/SDC Catalysts for the Reverse Water Gas Shift Reaction
}

\author{
Maxime Lortie ${ }^{1,2}$ and Rima J. Isaifan ${ }^{1,2}$ \\ ${ }^{1}$ Chemical and Biological Engineering, University of Ottawa, Ottawa, ON, Canada K1N 6N5 \\ ${ }^{2}$ Centre for Catalysis Research and Innovation, University of Ottawa, Ottawa, ON, Canada K1N 6N5 \\ Correspondence should be addressed to Maxime Lortie; m.lortie90@gmail.com
}

Received 6 October 2014; Revised 18 January 2015; Accepted 19 January 2015

Academic Editor: Hicham Idriss

Copyright (C) 2015 M. Lortie and R. J. Isaifan. This is an open access article distributed under the Creative Commons Attribution License, which permits unrestricted use, distribution, and reproduction in any medium, provided the original work is properly cited.

\begin{abstract}
$\mathrm{Cu}_{50} \mathrm{Ni}_{50}$ nanoparticles were synthesized using a modified polyol method and deposited on samarium-doped ceria, SDC, and yttria-stabilized zirconia, YSZ, supports to form reverse water-gas shift, RWGS, catalysts. The best CO yields, obtained with the $\mathrm{Cu}_{50} \mathrm{Ni}_{50} / \mathrm{SDC}$ catalyst, were about $90 \%$ of the equilibrium CO yields. In contrast CO yields using Pt/SDC catalysts were equal to equilibrium $\mathrm{CO}$ yields at $700^{\circ} \mathrm{C}$. Catalyst selectivity to $\mathrm{CO}$ was $100 \%$ at hydrogen partial pressures equal to $\mathrm{CO}_{2}$ partial pressures, $1 \mathrm{kPa}$, and decreased as methane was formed when the hydrogen partial pressure was $2 \mathrm{kPa}$ or greater. The reaction results were explained using a combination of Eley-Rideal and Langmuir-Hinshelwood mechanisms that involved adsorption on the metal surface and the concentration of oxygen vacancies in the support. Finally the $\mathrm{Cu}_{50} \mathrm{Ni}_{50} / \mathrm{SDC}$ catalyst was found to be thermally stable for 48 hours at $600 / 700^{\circ} \mathrm{C}$.
\end{abstract}

\section{Introduction}

The emission of carbon dioxide into the environment is viewed by many as a major contributor to global warming [1]. In spite of the current fossil fuel energy prices, the use of fossil fuels continues to increase resulting in more carbon dioxide emissions. Those emissions affect the state of the atmosphere and the state of the oceans.

Carbon capture and storage technologies are one means of diminishing $\mathrm{CO}_{2}$ emissions. Unfortunately, storing $\mathrm{CO}_{2}$ in underground caverns is not sustainable because all the caverns will eventually be filled. An alternative to carbon storage would be the reaction of $\mathrm{CO}_{2}$ with another chemical to obtain a useful product.

This work describes the reaction of carbon dioxide with hydrogen obtained from a renewable source. By hydrogenating $\mathrm{CO}_{2}[2,3]$, it is possible to obtain syngas via (1) or alcohols and hydrocarbons (using the Fischer-Tropsch process), via (2):

$$
\begin{gathered}
\mathrm{CO}_{2}+\mathrm{H}_{2} \longleftrightarrow \mathrm{CO}+\mathrm{H}_{2} \mathrm{O} \\
x \mathrm{CO}_{2}+\left(2 x-z+\frac{y}{2}\right) \mathrm{H}_{2} \longleftrightarrow \mathrm{C}_{x} \mathrm{H}_{y} \mathrm{O}_{z}+(2 x-z) \mathrm{H}_{2} \mathrm{O}
\end{gathered}
$$

Equation (1) is the reverse water-gas shift reaction (RWGS). Equation (2) is a synthesis reaction that is practiced on an industrial scale, the Fischer-Tropsch process. In (2) when $x=$ $1, y=4$, and $z=0$, methane $\left(\mathrm{CH}_{4}\right)$ is formed. It is a common by-product of the RWGS reaction. When $x=1, y=4$, and $z=1$, the product is methanol $\left(\mathrm{CH}_{3} \mathrm{OH}\right)$. When $z=0$ and $5<x<20$, a highly valued liquid hydrocarbon product is obtained.

An appropriate catalyst must satisfy several criteria. Because the equilibrium yield of CO from the RWGS reaction increases with temperature, thermal stability of the catalyst is one criterion. Others are rapid kinetics and selectivity to $\mathrm{CO}$ rather than to $\mathrm{CH}_{4}$.

Noble metals such as platinum $(\mathrm{Pt})$ have been studied and proven to be among the best RWGS catalysts because they have the ability to dissociate $\mathrm{H}_{2}$ [2]. Also, $\mathrm{Pt}$ is stable at high temperatures and produces both high $\mathrm{CO}$ selectivity and $\mathrm{CO}_{2}$ conversion [4-6]. However, noble metals such as Pt have a high cost.

Copper $(\mathrm{Cu})$ and nickel $(\mathrm{Ni})$ transition metals may be promising alternative catalysts to Pt noble metals. One indication is that both of these metals have produced promising 
results with the water gas shift, WGS, reaction $[2,7]$ that is shown in the following:

$$
\mathrm{CO}+\mathrm{H}_{2} \mathrm{O} \longleftrightarrow \mathrm{CO}_{2}+\mathrm{H}_{2}
$$

Good results were also obtained when they were tested individually on catalyst supports [4-6] using the RWGS reaction.

Metallic pure $\mathrm{Cu}$ catalysts have shown a tendency to deactivate over time when exposed to high temperatures [810]. Stabilizers have been used in an attempt to improve copper's thermal stability. Chen et al. [11] reported that an iron $(\mathrm{Fe})$ additive stabilized $\mathrm{Cu}$ supported on $\mathrm{SiO}_{2}$ at $600^{\circ} \mathrm{C}$ for up to $120 \mathrm{~h}$. It also increased $\mathrm{CO}_{2}$ conversion by $7 \%$. In contrast, $\mathrm{Cu}$ without Fe deactivated after only 5 hours on stream ultimately reaching $0 \%$ conversion after $120 \mathrm{~h}$. Other additives include potassium [12] and zinc oxide [9].

Chen et al. [13] showed that a Ni catalyst used for the RWGS reaction enhanced the formation of $\mathrm{CH}_{4}$ which is undesirable. They also investigated a Ni catalyst that was promoted with a potassium (K) additive. Although $\mathrm{K}$ increased the selectivity toward $\mathrm{CO}$, it also caused the formation of coke.

Y. Liu and D. Liu [14] made a bimetallic Ni and Cu catalyst and used it for the RWGS reaction. Their research was aimed at examining the effect of both metals on selectivity for the RWGS reaction. They found that an increase in catalyst $\mathrm{Ni}$ content generated greater $\mathrm{CH}_{4}$ yields while increased $\mathrm{Cu}$ contents generated greater $\mathrm{CO}$ selectivity.

Catalysts are often supported on materials such as $\gamma$ $\mathrm{Al}_{2} \mathrm{O}_{3}, \mathrm{SiO}_{2}$, and C. Yttria-stabilized zirconia, YSZ, and samarium-doped ceria, SDC, are two less common supports that have shown potential for the RWGS reaction $[15,16]$. Both contain oxygen vacancies.

Yttria-stabilized zirconia, $\mathrm{Y}_{0.15} \mathrm{Zr}_{0.85} \mathrm{O}_{1.925}$, is a combination of $0.15 * \mathrm{Y}_{2} \mathrm{O}_{3}$ and $0.85 \mathrm{ZrO}_{2}$. It is a conductive ceramic which has been used in solid oxide fuel cells and sensor technologies [17]. It is also used for the electrochemical promotion of catalysts, EPOC [18]. The purpose for doping $\mathrm{ZrO}_{2}$ with $\mathrm{Y}_{2} \mathrm{O}_{3}$ is twofold: (1) $\mathrm{Y}_{2} \mathrm{O}_{3}$ stabilizes the cubic fluorite structure eliminating volumetric variations caused by phase transformations, and (2) $\mathrm{Y}_{2} \mathrm{O}_{3}$ creates oxygen vacancies within the $\mathrm{ZrO}_{2}$ lattice $[19,20]$. Oxygen vacancies are important for all of the YSZ applications mentioned above. In addition oxygen vacancies in $\mathrm{ZrO}_{2}$ have been shown to affect the WGS reaction [7].

Similarly, adding dopants to ceria, $\mathrm{CeO}_{2}$, increases the oxygen vacancies within the crystal lattice [8]. Doping with cations having an ionic radius and electronegativity close to $\mathrm{CeO}_{2}$ is considered to be the most appropriate [21]. Samarium showed the greatest resistance to reduction of the $\mathrm{CeO}_{2}$ support [22] among the doping agents investigated. Since the intent of the work was to examine the effect of oxygen vacancies and not the reducibility of the support, samarium was chosen as the dopant. $\mathrm{Sm}_{0.2} \mathrm{Ce}_{0.8} \mathrm{O}_{1.9}$ (SDC) is a combination of $0.2 * \mathrm{Sm}_{2} \mathrm{O}_{3}$ and $0.8 * \mathrm{CeO}_{2}$.

YSZ and SDC have different oxygen vacancy contents. Samarium-doped ceria, $\mathrm{Sm}_{0.2} \mathrm{Ce}_{0.8} \mathrm{O}_{1.9}$, has 0.1 oxygen vacancies per cation when compared to $\mathrm{CeO}_{2}$. In contrast, yttriastabilized zirconia, $\mathrm{Y}_{0.15} \mathrm{Zr}_{0.85} \mathrm{O}_{1.926}$, has 0.074 oxygen vacancies per cation when compared to $\mathrm{ZrO}_{2}$. Both of these materials have been tested by themselves without the addition of other metals and have demonstrated thermal stability and $\mathrm{CO}_{2}$ conversion [15].

In the present work, $\mathrm{Cu}_{50} \mathrm{Ni}_{50}$ nanoparticles were synthesized using a modified polyol technique and deposited on SDC and YSZ supports. The SDC and YSZ supported catalysts were compared to catalysts containing Pt nanoparticles deposited on the same supports at the same reaction conditions. The $\mathrm{Cu}_{50} \mathrm{Ni}_{50}$ catalyst with the best performance was examined for thermal stability experiments in which the temperature was maintained between 600 and $700^{\circ} \mathrm{C}$ for $48 \mathrm{~h}$.

\section{Experimental}

2.1. Catalyst Preparation. The synthesis of CuNi nanoparticles was achieved using a modified polyol technique. First, $314.5 \mathrm{mg}$ of nickel nitrate $\left(\mathrm{Ni}\left(\mathrm{NO}_{3}\right)_{2}\right)$ (hexahydrate $99.999 \%$ metal basis, Alfa Aesar) was dissolved in $30 \mathrm{~mL}$ of ethylene glycol (anhydrous 99.8\%, SigmaAldrich) to obtain a green solution. That solution's $\mathrm{pH}$ was then increased to 11 via the addition of $199 \mathrm{mg}$ of sodium hydroxide $(\mathrm{NaOH})$ pellets (EM Science, ACS grade) to obtain Solution 1. This caused the solution to slightly darken. In a separate beaker, $321.8 \mathrm{mg}$ of copper nitrate $\left(\mathrm{Cu}\left(\mathrm{NO}_{3}\right)_{2}\right)$ (hexahydrate $99.999 \%$ metal basis, Alfa Aesar) was dissolved in $30 \mathrm{~mL}$ of ethylene glycol to obtain a blue solution. Its $\mathrm{pH}$ was also increased to 11 using $199 \mathrm{mg}$ of $\mathrm{NaOH}$ pellets to obtain Solution 2. Solution 2 also darkened. Following this, Solution 1 was poured into a round bottom flask, refluxed, and stirred at $196^{\circ} \mathrm{C}$. Once the temperature reached $196^{\circ} \mathrm{C}$, Solution 2 , at room temperature, was added to the round bottom flask. The ratio of Solution 1 to Solution 2 was selected to obtain CuNi colloidal particles of $50 \mathrm{wt} \% \mathrm{Cu} / 50 \mathrm{wt} \% \mathrm{Ni}$ (nominally $\mathrm{Cu}_{50} \mathrm{Ni}_{50}$ ). The combined solution was refluxed at $196^{\circ} \mathrm{C}$ for 30 minutes and then cooled. The combined solution gradually became dark brown in colour. Once cooled, the colloidal particles were stored in the ethylene glycol solution. The final $\mathrm{pH}$ of the combined solution was 7 .

The colloidal particles were then deposited on supports using a wet impregnation technique. A powdered support was placed into a beaker and subsequently an amount of the combined solution was poured unto the powder. The amount of combined solution was chosen to result in nominally $10 \mathrm{wt} \%$ of $\mathrm{CuNi}$ when deposited on the supports, which corresponds to a $\mathrm{Cu}_{50} \mathrm{Ni}_{50}$ metal/support ratio of 1 to 9. The solution/support was sonicated for 1 hour and stirred for 24 hours. The supported metal was then centrifuged and washed with deionized water several times to remove the salts remaining after the synthesis procedure. The supports were yttria-stabilized zirconia (Tosoh, BET surface area $14.8 \mathrm{~m}^{2} \cdot \mathrm{g}^{-1}$ ) and samarium-doped ceria (FCM, BET surface area $\left.31.0 \mathrm{~m}^{2} \cdot \mathrm{g}^{-1}\right)$. The catalyst was then dried using a freeze dryer. Prior to any experiments, the catalyst was crushed.

Pt nanoparticles were synthesized using a polyol method as described elsewhere [23]. It involved diluting $\mathrm{PtCl}_{4}$ in a $0.06 \mathrm{M} \mathrm{NaOH}$ solution of ethylene glycol. The mixture was then refluxed at $160^{\circ} \mathrm{C}$ for 3 hours. The deposition technique was the same as that for $\mathrm{Cu}_{50} \mathrm{Ni}_{50}$ and the same supports were 
used. After deposition, each support contained $1 \mathrm{wt} \%$ of $\mathrm{Pt}$ nanoparticles.

2.2. Physical Characterization. X-ray diffraction (XRD) measurements were made on the CuNi colloidal particles using a Rigaku Ultima IV diffractometer which used a $\mathrm{Cu} \mathrm{K} \alpha \mathrm{X}$-ray $(40 \mathrm{ma}, 44 \mathrm{kV}$ ) operating with focused beam geometry and a divergence slit of $2 / 3$ degree, a scan speed of $0.17 \mathrm{deg} \mathrm{min}^{-1}$, and a scan step of 0.06 degrees were used while operating between $35^{\circ}$ and $55^{\circ}$.

Characterization of the CuNi metal particles by scanning electron microscopy, SEM, and X-ray photoelectron spectroscopy has been reported previously [24]. Characterization of the Pt metal particles by transmission electron microscopy, TEM, has also been reported previously [25]. The characterization measurements were made with the metal particles supported on carbon, in order to avoid electrostatic charging that would occur when metals are supported on insulating materials.

2.3. Catalytic Performance. Catalytic reaction rates were measured on both $\mathrm{Cu}_{50} \mathrm{Ni}_{50}$ and Pt supported nanoparticles for the RWGS reaction. First, the dry metal/support catalyst was finely crushed. Then, $50 \mathrm{mg}$ of the metal/support catalyst was placed on top of a fritted quartz bed located within a tubular, $35 \mathrm{~mL}$ quartz reactor. A gaseous mixture containing $1 \mathrm{kPa} \mathrm{H}_{2}$ (Grade 4.0, Linde) and $1 \mathrm{kPa} \mathrm{CO}_{2}$ (Grade 3.0, Linde) with the balance being $\mathrm{He}$ (Grade 4.7 Linde) flowed through the reactor at a flow rate of $510 \mathrm{~mL} \cdot \mathrm{min}^{-1}$. The reaction was performed at a total pressure of $1 \mathrm{~atm}$ using three consecutive temperature cycles. Each temperature cycle consisted of a series of experiments over the temperature range from $400^{\circ} \mathrm{C}$ to $700^{\circ} \mathrm{C}$. Before each experiment, the temperature was held constant for $30 \mathrm{~min}$. The same mass of catalyst was used in each experiment, $50 \mathrm{mg}$, so that the weight hourly space velocity was constant at $612 \mathrm{~L} /(\mathrm{hg})$. Nevertheless, the gas hourly space velocity (GHSV) was different because the supports had different bulk densities (1187 g/L for the YSZ support and $1570 \mathrm{~g} / \mathrm{L}$ for the SDC support). The GHSV values were $716000 \mathrm{~h}^{-1}$ and $960800 \mathrm{~h}^{-1}$, respectively, for CuNi/YSZ and $\mathrm{CuNi} / \mathrm{SDC}$ catalysts. The effluent was dehumidified by flowing through an adsorbent and was analyzed by flowing through a mass spectrometer (Ametek Proline DM 100) and a nondispersive infrared CO gas analyzer (Horiba VIA-510). Each set of experiments was repeated three times $(24 \mathrm{hrs}$ total) in order to examine reproducibility and stability.

A schematic of the experimental equipment is shown in Figure 1.

The yield of $\mathrm{CO}$ was calculated using the following formula:

$$
\text { Yield of } \mathrm{CO}(\%)=\frac{[\mathrm{CO}]_{\text {out }}}{\left[\mathrm{CO}_{2}\right]_{\text {in }}} \times 100 \%
$$

The quantitative measurements obtained using the NDIR $\mathrm{CO}$ analyzer were used to obtain the concentration of $\mathrm{CO}$ coming out of the reactor $\left([\mathrm{CO}]_{\text {out }}\right)$. The mass spectrometer identified any by-products that were formed via side reactions such as $\mathrm{CO}$ methanation. The mass spectrometer indicated

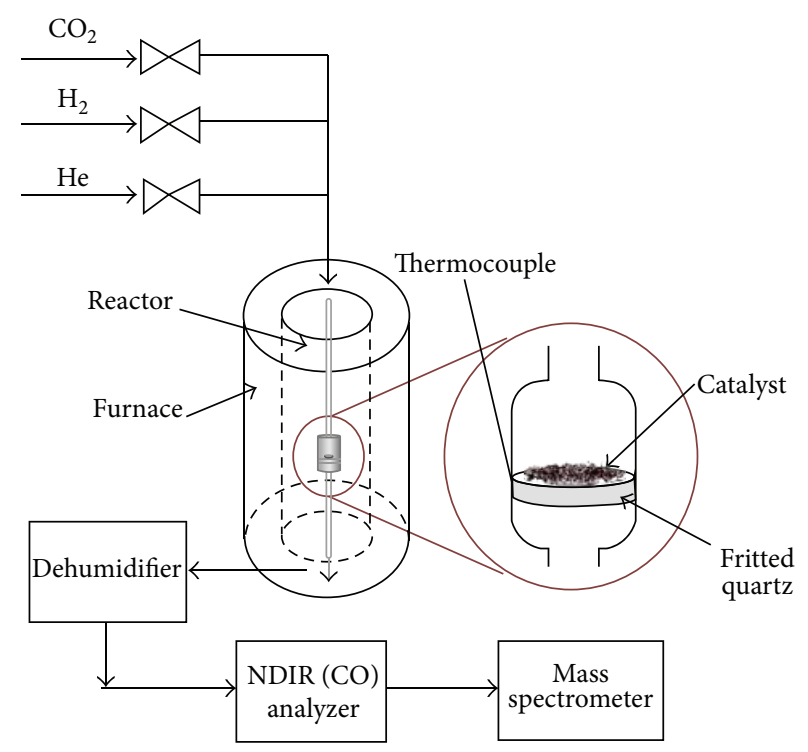

FIGURE 1: Schematic of experimental setup used for catalytic testing of the RWGS reaction.

the presence of gases with a molecular weight of up to 50 atomic units and had a detection limit of $50 \mathrm{ppm}$.

Thermal stability experiments were performed on the $\mathrm{Cu}_{50} \mathrm{Ni}_{50} / \mathrm{SDC}$ catalyst by maintaining the temperature at $700^{\circ} \mathrm{C}$ for $24 \mathrm{hrs}$ at a total pressure of $1 \mathrm{~atm}$ and a total flow rate of $510 \mathrm{~mL} \cdot \mathrm{min}^{-1}$. The gas composition was $1 \mathrm{kPa}$ $\mathrm{H}_{2}$ and $1 \mathrm{kPa} \mathrm{CO}_{2}$ with the balance being $\mathrm{He}$. Subsequently, the temperature was decreased to $600^{\circ} \mathrm{C}$ and maintained constant for another $24 \mathrm{hrs}$, for a total catalyst time-onstream of $48 \mathrm{hrs}$.

Thermodynamic equilibrium calculations were performed using UniSim simulation software. A Gibbs reactor calculation was used to determine the equilibrium conversion at the operating conditions. Equilibrium conversions were compared with experimental results.

\section{Results and Discussion}

3.1. Physical Characterization of $\mathrm{Cu}_{50} \mathrm{Ni}_{50}$. X-ray diffraction spectra of $\mathrm{Cu}_{50} \mathrm{Ni}_{50}$ nanoparticles are shown in Figure 2. Ni and $\mathrm{Cu}$ were the major species and no nitrate salts were present. X-ray diffraction peaks having $2 \theta$ values of $43.39^{\circ}$ and $44.41^{\circ}$ were attributed, respectively, to reflections from the 111 planes of a $\mathrm{Cu}$ rich alloy and from the 111 planes of a $\mathrm{Ni}$ rich alloy as shown in [24]. The crystalline size was obtained using Scherrer's formula and gave $20.5 \mathrm{~nm}$ for the $\mathrm{Cu}$ rich (111) peak and $9.6 \mathrm{~nm}$ for the Ni rich (111) peak.

SEM images were used to measure particle size, shape, and dispersion on a carbon support. A carbon support was used for SEM because carbon would have less electron static charging than YSZ or SDC. Two images are shown in Figure 3 for both COMPO, composition, and LEI, lower secondary electron image, settings.

Light coloured regions are indicative of $\mathrm{Cu}_{50} \mathrm{Ni}_{50}$ particles and the darker coloured background represents the $\mathrm{C}$ support. These images show good dispersion of the metal on 


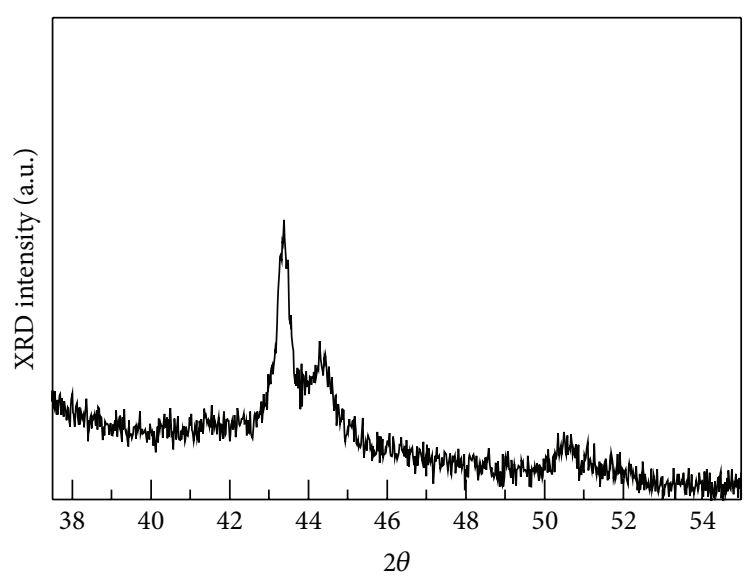

FIGURE 2: $\mathrm{XRD}$ of $\mathrm{Cu}_{50} \mathrm{Ni}_{50}$ colloidal solution.

the support and also indicate agglomeration. Antiagglomerating agents like polyvinylpyrrolidone (PVP) were not used to minimize the cost of the synthesis materials. A typical particle size observed in multiple SEM spectra was $30 \mathrm{~nm}$.

3.2. Catalytic Performance. The only observable components in the gas stream entering the mass spectrometer were $\mathrm{CO}_{2}$, $\mathrm{H}_{2}$, CO, trace amounts of $\mathrm{H}_{2} \mathrm{O}$, and carrier gas, He. These results indicate that $\mathrm{CO}$ was the main product having a typical concentration of $2000 \mathrm{ppm}$. Other products including $\mathrm{CH}_{4}$ had concentrations of less than the detection limit of the spectrometer, $50 \mathrm{ppm}$. These results with the $\mathrm{CuNi} / \mathrm{YSZ}$ and $\mathrm{CuNi} / \mathrm{SDC}$ catalysts were completely consistent with previous work using $\mathrm{CuNi} / \mathrm{C}$ and $\mathrm{CuNi} / \mathrm{Al}_{2} \mathrm{O}_{3}$ catalysts [24].

$\mathrm{CO}$ and $\mathrm{CH}_{4}$ were the expected products with pure copper catalysts $[9,11,14,26]$ and pure nickel catalysts [14], respectively. The absence of $\mathrm{CH}_{4}$ in this work might have been caused by the enhanced copper concentration on the catalyst surface. XPS analysis reported previously for $\mathrm{Cu}_{50} \mathrm{Ni}_{50} / \mathrm{C}$ catalysts [24] indicated that the surface atomic $\mathrm{Cu} / \mathrm{Ni}$ was " 2 ," even though the bulk atomic $\mathrm{Cu} / \mathrm{Ni}$ rate was "1." Perhaps any $\mathrm{CO}$ formed on $\mathrm{Ni}$ atom sites may have "spilled over" to $\mathrm{Cu}$ atom sites and desorbed prior to further hydrogenation to $\mathrm{CH}_{4}$.

The data in Figure 4 were obtained when the RWGS reaction was performed with a catalyst composed of platinum supported on a YSZ support. The CO yields obtained during all of the cycles were similar at 400 and $450^{\circ} \mathrm{C}$. In contrast the $\mathrm{CO}$ yields at 650 and $700^{\circ} \mathrm{C}$ for the third cycle were slightly less than those during the first and second cycles.

Figure 5 demonstrates the results obtained when the RWGS reaction was performed over a catalyst composed of $\mathrm{CuNi}$ nanoparticles supported on a YSZ support. The CO yields obtained during the second and third cycles were similar and were somewhat less than those obtained during the first cycle. It indicates that while some deactivation had occurred, the catalysts became thermally stable after the first cycle. $\mathrm{Cu}$ alone is known to be unstable at high temperatures $[9,11,26]$. It may be that the $\mathrm{Ni}$ in $\mathrm{Cu}_{50} \mathrm{Ni}_{50}$ stabilizes $\mathrm{Cu}$ so that the Ni provides the desired thermal stability and the $\mathrm{Cu}$ provides the desired $\mathrm{CO}$ yields.

The data in Figure 6 shows the results obtained when Pt supported on a samarium-doped ceria support was used for the RWGS reaction. The $\mathrm{CO}$ yields obtained during the second and third cycles were superior to those obtained during the first cycle. This might be caused by a reduction of Pt oxide particles on the surface of the catalyst to metal Pt. Once reduced, its catalytic performance appears to be stable. The fact that similar CO yields were obtained during the second and third cycles indicates that no deactivation was apparent. The thermal stability shown by Pt was expected based on previous reports [16, 27-29]. The CO yields obtained with the Pt/SDC catalyst in Figure 6 were superior to those obtained with the Pt/YSZ catalyst in Figure 4.

The data in Figure 7 were obtained when CuNi nanoparticles supported on a samarium-doped ceria support were used for the RWGS reaction. The CO yields obtained during all of the cycles were virtually the same, indicating that the catalyst was thermally stable and that there was no deactivation. The $\mathrm{CO}$ yields obtained with the $\mathrm{Cu}_{50} \mathrm{Ni}_{50} / \mathrm{SDC}$ catalyst in Figure 7 were superior to those obtained with the $\mathrm{Cu}_{50} \mathrm{Ni}_{50} /$ YSZ catalyst in Figure 5 .

The average yields of the two Pt catalysts are compared with the equilibrium $\mathrm{CO}$ yield in Figure 8 . The $\mathrm{CO}$ yield with the Pt/SDC catalyst is better than that with the Pt/YSZ catalyst at all temperatures. The $\mathrm{CO}$ yield with the $\mathrm{Pt} / \mathrm{YSZ}$ catalyst was always less than the equilibrium $\mathrm{CO}$ yield. Although the $\mathrm{CO}$ yield with the $\mathrm{Pt} / \mathrm{SDC}$ catalyst was less than the equilibrium yield at lower temperatures, at $700^{\circ} \mathrm{C}$ the equilibrium $\mathrm{CO}$ yield was attained using the $\mathrm{Pt} / \mathrm{SDC}$ catalyst.

The average yields of the two $\mathrm{Cu}_{50} \mathrm{Ni}_{50}$ catalysts are compared with the equilibrium yield in Figure 9. The $\mathrm{CO}$ yield with the $\mathrm{Cu}_{50} \mathrm{Ni}_{50} / \mathrm{SDC}$ catalyst is better than that with the $\mathrm{Cu}_{50} \mathrm{Ni}_{50} / Y S Z$ catalyst at all temperatures. In addition the $\mathrm{CO}$ yields with both catalysts are less than the equilibrium $\mathrm{CO}$ yields at all temperatures.

For both $\mathrm{Pt}$ and $\mathrm{Cu}_{50} \mathrm{Ni}_{50}$ catalysts the $\mathrm{CO}$ yields were greater with the SDC support than with the YSZ support. This is consistent with data reported by Dow and Huang [19] for SDC and YSZ supports that did not contain $\mathrm{Cu}_{50} \mathrm{Ni}_{50}$. [15]. The CO yields may be related to the concentration of bulk phase oxygen vacancies in the two supports, 0.1 for SDC and 0.074 for YSZ.

Two supports having no bulk phase oxygen vacancies, $\mathrm{C}$ and $\gamma-\mathrm{Al}_{2} \mathrm{O}_{3}$, were investigated in previous work [24]. Their results with $\mathrm{Cu}_{50} \mathrm{Ni}_{50}$ nanoparticles were combined with the $\mathrm{Cu}_{50} \mathrm{Ni}_{50}$ nanoparticle results on YSZ and SDC supports and are shown in Figure 10. The $\mathrm{CO}$ yields in Figure 10 are definitely correlated with the oxygen vacancy content of the support. Other reaction results have also been correlated with oxygen vacancies. For example, the results Pekridis et al. [16] obtained using a solid oxide fuel cell (SOFC) at $650-800^{\circ} \mathrm{C}$ were explained in terms of oxygen vacancies.

The catalysts containing carbon and $\gamma-\mathrm{Al}_{2} \mathrm{O}_{3}$ supports had measurable $\mathrm{CO}$ yields even though they did not contain bulk phase oxygen vacancies. The surfaces of $\gamma-\mathrm{Al}_{2} \mathrm{O}_{3}$ contain oxygen vacancies. During the preparation of $\gamma-\mathrm{Al}_{2} \mathrm{O}_{3}$, hydroxyl groups are formed on the solid surface. When 


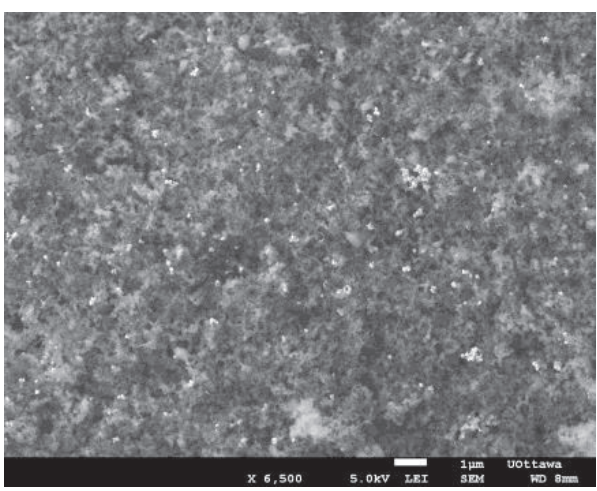

(a)

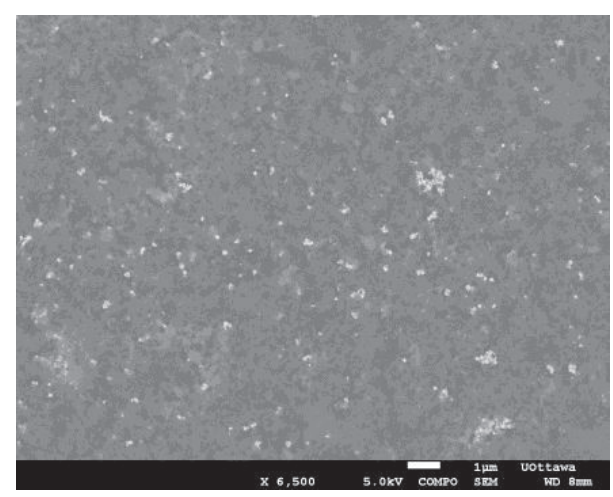

(b)

FIgURE 3: SEM of $\mathrm{Cu}_{50} \mathrm{Ni}_{50} / \mathrm{C}$ in (a) LEI mode and (b) COMPO mode.

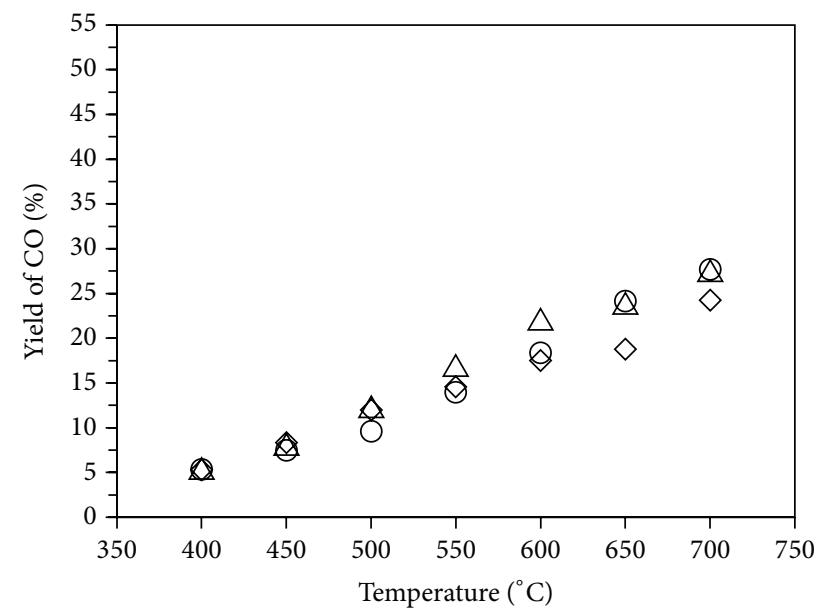

Figure 4: RWGS reaction at $1 \mathrm{~atm}, P_{\mathrm{H} 2}=P_{\mathrm{CO} 2}=1 \mathrm{kPa}$, balance $\mathrm{He}$, $\mathrm{GHSV}=716000 \mathrm{~h}^{-1}, 50 \mathrm{mg}$ of catalyst: Pt/YSZ, $1 \mathrm{wt} \%$ catalyst where $\mathrm{O}=1$ st cycle, $\Delta=2$ nd cycle, and $\diamond=3$ rd cycle.

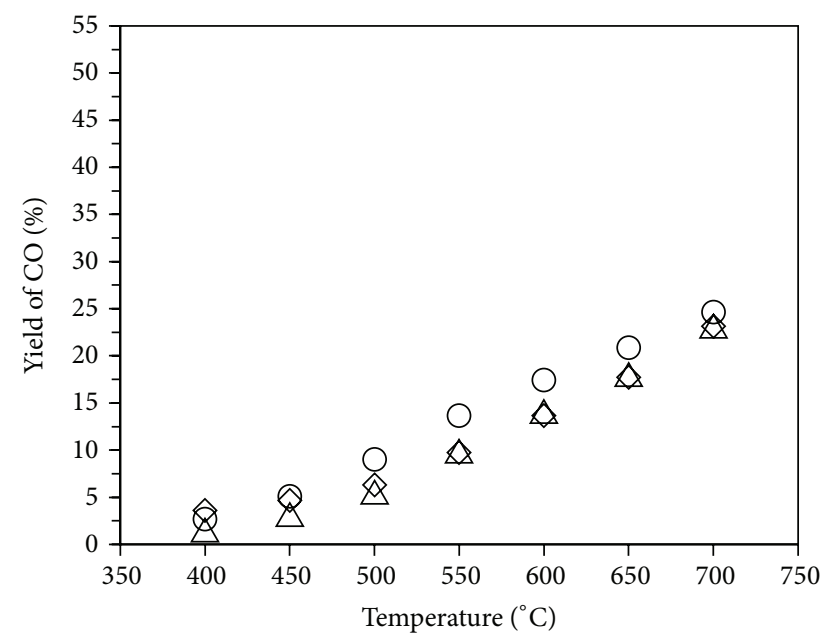

Figure 5: RWGS reaction at $1 \mathrm{~atm}, P_{\mathrm{H} 2}=P_{\mathrm{CO} 2}=1 \mathrm{kPa}$, balance $\mathrm{He}, \mathrm{GHSV}=716000 \mathrm{~h}^{-1}, 50 \mathrm{mg}$ of catalyst: $\mathrm{Cu}_{50} \mathrm{Ni}_{50} / \mathrm{YSZ}, 10 \mathrm{wt} \%$ catalyst where $O=1$ st cycle, $\Delta=2$ nd cycle, and $\diamond=3$ rd cycle.

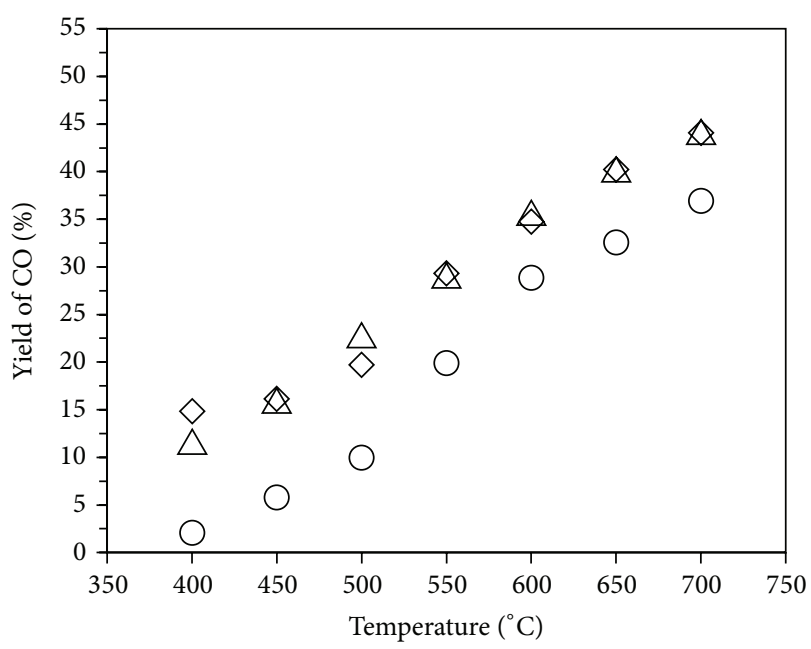

FIgURe 6: RWGS reaction at $1 \mathrm{~atm}, P_{\mathrm{H} 2}=P_{\mathrm{CO} 2}=1 \mathrm{kPa}$, balance He, $\mathrm{GHSV}=960800 \mathrm{~h}^{-1}, 50 \mathrm{mg}$ of catalyst: $\mathrm{Pt} / \mathrm{SDC}, 1 \mathrm{wt} \%$ catalyst where $\mathrm{O}=1$ st cycle, $\Delta=2$ nd cycle, and $\diamond=3$ rd cycle.

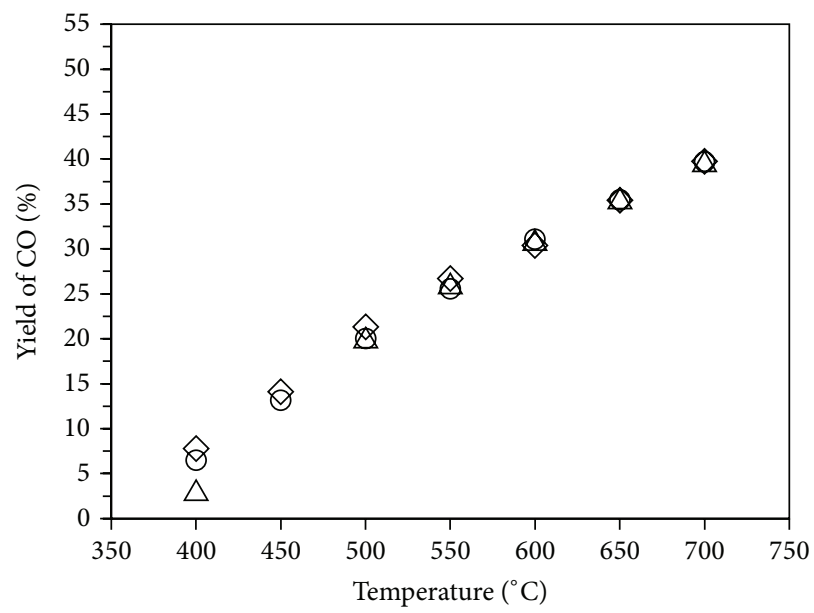

Figure 7: RWGS reaction at $1 \mathrm{~atm}, P_{\mathrm{H} 2}=P_{\mathrm{CO} 2}=1 \mathrm{kPa}$, balance $\mathrm{He}, \mathrm{GHSV}=960800 \mathrm{~h}^{-1}, 50 \mathrm{mg}$ of catalyst: $\mathrm{Cu}_{50} \mathrm{Ni}_{50} / \mathrm{SDC}, 10 \mathrm{wt} \%$ catalyst where $O=1$ st cycle, $\Delta=2$ nd cycle, and $\diamond=3$ rd cycle. 


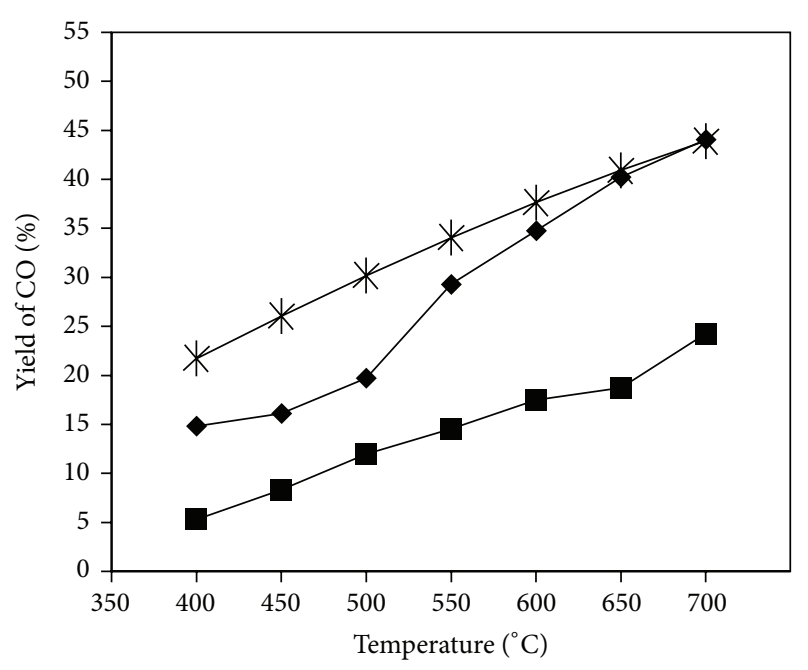

FIgure 8: Average yield of CO for the RWGS reaction using Pt supported on SDC and YSZ at $1 \mathrm{~atm}$. Total flow rate of $510 \mathrm{~mL} \cdot \mathrm{min}^{-1}$, $P_{\mathrm{CO} 2}=P_{\mathrm{H} 2}=1 \mathrm{kPa}$, balance He. $*=$ equilibrium, $\bullet=\mathrm{Pt} / \mathrm{SDC}$, and - $=\mathrm{Pt} / \mathrm{YSZ}$.

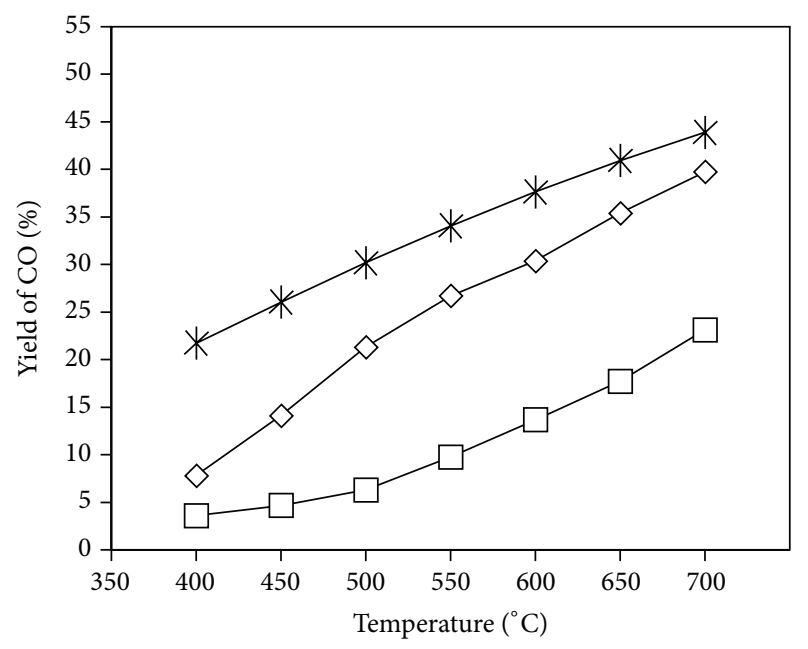

FIGURE 9: Average yield of CO for the RWGS reaction using $\mathrm{Cu}_{50} \mathrm{Ni}_{50}$ supported on SDC and YSZ at $1 \mathrm{~atm}$. Total flow rate of $510 \mathrm{~mL} \cdot \mathrm{min}^{-1}, P_{\mathrm{CO} 2}=P_{\mathrm{H} 2}=1 \mathrm{kPa}$, balance He. $*=$ equilibrium, $\diamond=\mathrm{Cu}_{50} \mathrm{Ni}_{50} / \mathrm{SDC}$, and $\square=\mathrm{Cu}_{50} \mathrm{Ni}_{50} / \mathrm{YSZ}$.

the solid is heated some of the hydroxyl groups combine to form a water molecule that enters the gas phase [30]. An oxygen anion and an oxygen vacancy are left behind on the solid alumina surface. The surfaces of carbon particles contain various oxygen groups including hydroxyls and carboxyls. When hydrogen is present at the reaction conditions of these experiments, water can be formed and enter the gas phase, leaving surface oxygen vacancies on the surface. Although the carbon and $\gamma-\mathrm{Al}_{2} \mathrm{O}_{3}$ supports do not contain bulk phase oxygen vacancies, they do contain surface oxygen vacancies. The presence of surface oxygen vacancies would be consistent with the $\mathrm{CO}$ yields they obtained.

A diagram illustrating the bifunctional nature of the catalyst is shown in Figure 11. A catalytic mechanism can

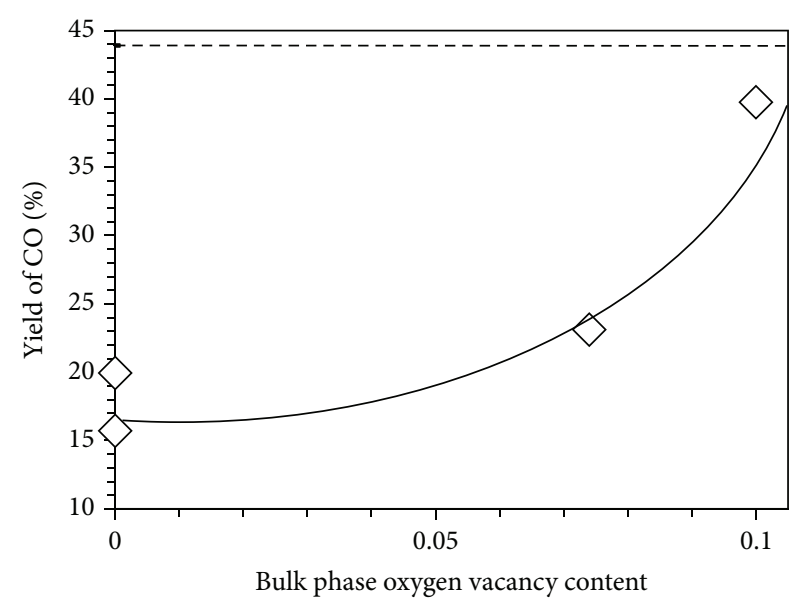

FIGURE 10: CO yield versus bulk phase oxygen content in supports containing $\mathrm{Cu}_{50} \mathrm{Ni}_{50}$ nanoparticles at $700^{\circ} \mathrm{C}$ and $1 \mathrm{~atm}$. Total flow rate of $510 \mathrm{~mL} \cdot \mathrm{min}^{-1}, P_{\mathrm{CO} 2}=P_{\mathrm{H} 2}=1 \mathrm{kPa}$, balance He.

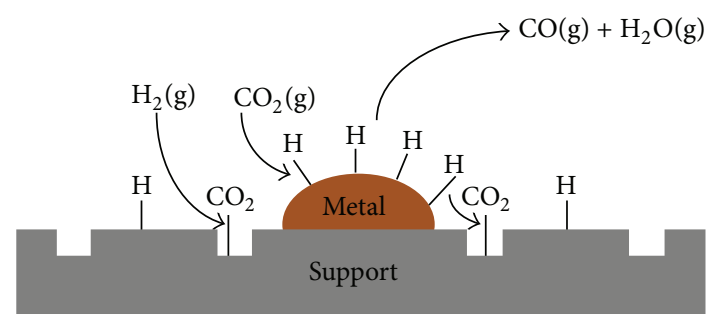

FIGURE 11: Diagram showing adsorbed species on the surface of a bifunctional catalyst operating through an Eley-Rideal and a Langmuir Hinshelwood mechanism.

be suggested which involves the adsorption of hydrogen on the CuNi metal phases and the adsorption of carbon dioxide on the support. The amount of $\mathrm{H}_{2}$ adsorbed on pure $\mathrm{Ni}$ is known to be five times greater than that adsorbed on pure $\mathrm{Cu}$ [31]. The amount of hydrogen adsorbed on $\mathrm{CuNi}$ alloys does not vary much with alloy composition and is approximately one-third of that adsorbed on pure $\mathrm{Ni}$ [31]. $\mathrm{CO}_{2}$ adsorption on YSZ has been reported as a bicarbonate species [32]. Although we are not aware of any SDC data, $\mathrm{CO}_{2}$ adsorption has also been reported on gallium doped ceria as a bicarbonate species [33].

Based on the above, the adsorption of the reactants can be expressed in the form of equations. $\mathrm{CO}_{2}$ adsorbed on support oxygen vacancies, $\mathrm{V}_{\mathrm{o}}{ }^{x}(\mathrm{~S})$, might be represented as shown in the following:

$$
\mathrm{CO}_{2}(\mathrm{~g})+\mathrm{V}_{\mathrm{o}}^{x}(\mathrm{~S})=\mathrm{CO}_{2}(\mathrm{ads})-\mathrm{Sup}
$$

Hydrogen from the gas phase might be dissociatively adsorbed on the surface of the metal, where the electron on a dissociated hydrogen radical is shared with an empty orbital in the conduction band of the metal, $\square_{\mathrm{Me}}$, as shown in the following:

$$
\mathrm{H}_{2}(\mathrm{~g})+2 \square_{\mathrm{Me}}=2 \mathrm{H}(\mathrm{ads})-\mathrm{Me}
$$


Eley-Rideal mechanisms might be operative in two ways. Hydrogen from the gas phase might react with adsorbed $\mathrm{CO}_{2}$ as shown in the following:

$$
\begin{gathered}
\frac{1}{2} \mathrm{H}_{2}(\mathrm{~g})+\mathrm{CO}_{2}(\text { ads })-\text { Sup }=\mathrm{OCOH}(\text { ads })-\text { Sup } \\
\frac{1}{2} \mathrm{H}_{2}(\mathrm{~g})+\mathrm{OCOH}(\mathrm{ads})-\mathrm{Sup}=\mathrm{CO}(\mathrm{g})+\mathrm{H}_{2}(\mathrm{~g})+\mathrm{V}_{\mathrm{o}}^{x}(\mathrm{~S})
\end{gathered}
$$

Since the $\mathrm{CO}_{2}$ adsorbed on the support reacts with hydrogen in the gas phase, it could reduce $\mathrm{CO}_{2}$ to $\mathrm{CO}$ even if the catalyst did not contain metal particles, as was shown in other work reported by Ismail [15]. In his work, he described both YSZ and SDC catalysts that converted $\mathrm{CO}_{2}$ to other products without a metallic component in the catalyst.

A second Eley-Rideal mechanism would occur if $\mathrm{CO}_{2}$ in the gas phase reacted with adsorbed $\mathrm{H}_{2}$ as shown in (9). Vesselli et al. [34, 35] have described the occurrence of the Eley-Rideal mechanism in RWGS reactions:

$$
\mathrm{CO}_{2}(\mathrm{~g})+2 \mathrm{H}(\text { ads })-\mathrm{Me}=\mathrm{CO}(\mathrm{g})+\mathrm{H}_{2} \mathrm{O}(\mathrm{g})+2 \square_{\mathrm{Me}}
$$

A Langmuir-Hinshelwood mechanism might also be possible. The adsorbed hydrogen might react with the adsorbed $\mathrm{CO}_{2}$ at the three-phase (metal-support-gas) boundary, as shown in (10). Alternatively, the hydrogen adsorbed on the metal surface diffuses from the metal surface unto the support surface prior to reacting via (10) (hydrogen spillover). The resulting species, $\mathrm{OCOH}(\mathrm{ads})$, might diffuse over a support surface by hopping from one oxygen vacancy to another until two $\mathrm{OCOH}(\mathrm{ads})$ species were adjacent to one another:

$$
\begin{gathered}
\mathrm{H} \text { (ads) - } \mathrm{Me}+\mathrm{CO}_{2} \text { (ads) -Sup } \\
=\mathrm{OCOH} \text { (ads) -Sup }+\square_{\mathrm{Me}}
\end{gathered}
$$

which might yield the reaction via the following:

$$
\begin{aligned}
2 \mathrm{OCOH}(\mathrm{ads})-\mathrm{Sup}= & \mathrm{CO}_{2}(\mathrm{ads})-\mathrm{Sup} \\
& +\mathrm{V}_{\mathrm{o}}{ }^{x}(\mathrm{~S})+\mathrm{CO}(\mathrm{g})+\mathrm{H}_{2} \mathrm{O}(\mathrm{g})
\end{aligned}
$$

The rate of surface diffusion might be influenced by the concentration of oxygen vacancies on the support surface. In this case the reaction would occur on an extended region of the support surface surrounding the three-phase boundary. Kim et al. [5] proposed a similar Langmuir-Hinshelwood mechanism to explain results obtained with a solid oxide fuel cell.

3.3. Stability Measurements. Time-on-stream experiments were performed in order to examine the catalyst's thermal stability over a 48 -hour period, 24 hours at $700^{\circ} \mathrm{C}$ and subsequently another 24 hours at $600^{\circ} \mathrm{C}$ without cooling down the catalyst. The results are shown in Figure 12. No deactivation was apparent.

This is a significant achievement in the use of a $\mathrm{Cu}$ catalyst for the RWGS reaction. Previous studies suggested that $\mathrm{Cu}$ is inadequate for use at high temperatures because of its tendency to deactivate over time [11, 12]. In fact,

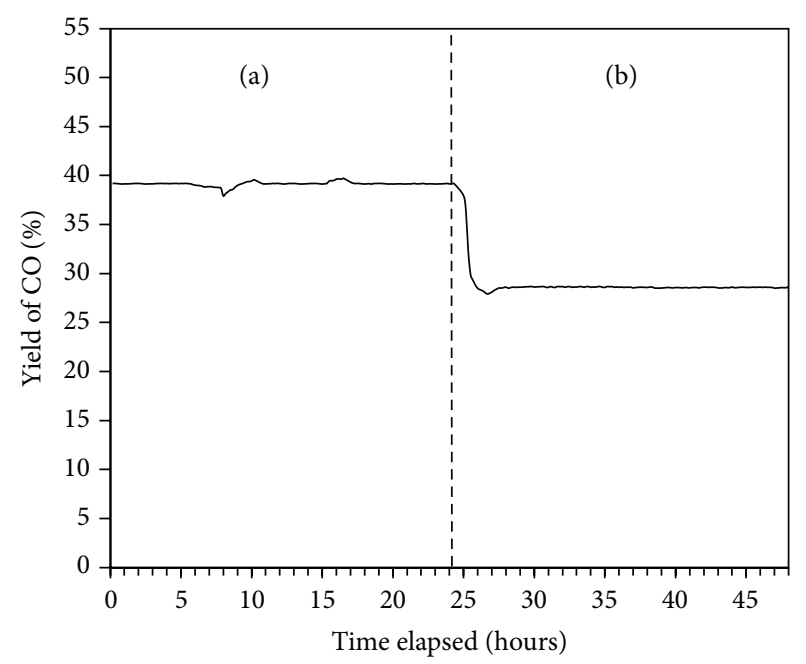

FIGURE 12: Stability measurements of $\mathrm{Cu}_{50} \mathrm{Ni}_{50} / \mathrm{SDC}$ for 2 consecutive days of testing at (a) $700^{\circ} \mathrm{C}$ and (b) $600^{\circ} \mathrm{C}$. GHSV $=960800 \mathrm{~h}^{-1}$. Total flow rate of $510 \mathrm{~mL} \cdot \mathrm{min}^{-1}$.

$\mathrm{Cu} / \mathrm{SiO}_{2}$ began deactivating after 5 hours on stream. After 48 hours, conversion was down to approximately half the initial conversion when the catalyst was used at $600^{\circ} \mathrm{C}$ [12]. In contrast, the results in Figure 12 demonstrate $\mathrm{CO}$ yields that approached the equilibrium $\mathrm{CO}$ yield and suggest long-term thermal stability.

The favorable results reported here can probably be attributed to $\mathrm{Cu}$ being used as a $\mathrm{CuNi}$ alloy catalyst. The $\mathrm{Ni}$ component is most likely responsible for the thermal stability. Other research has also shown that $\mathrm{Ni}$ can stabilize $\mathrm{Cu}$ when both metals were deposited on carbon. Specifically, a 16-hour stability period was demonstrated with a $\mathrm{Cu}_{50} \mathrm{Ni}_{50} / \mathrm{C}$ catalyst [24]. The $100 \%$ selectivity to CO may be attributed to the $\mathrm{CuNi}$ alloy surface having a much greater concentration of $\mathrm{Cu}$ than the bulk CuNi alloy. A large surface concentration of $\mathrm{Cu}$ diminishes the tendency for $\mathrm{CH}_{4}$ to be formed on $\mathrm{Ni}$.

All of the results reported here were obtained at small partial pressures of hydrogen. The experiments performed at $\mathrm{H}_{2}$ partial pressures of $2 \mathrm{kPa}$ and greater showed (with the $\mathrm{CO}_{2}$ partial pressure constant at $2 \mathrm{kPa}$ ) that $\mathrm{CH}_{4}$ was formed and that $100 \%$ selectivity to $\mathrm{CO}$ was not obtained. There may be merit in performing future experiments at greater hydrogen partial pressures with $\mathrm{CuNi}$ alloy catalysts that have larger $\mathrm{Cu} / \mathrm{Ni}$ ratios than the one used in this investigation, since it is known [24] that the surface $\mathrm{Cu} / \mathrm{Ni}$ ratio increases nonlinearly with the bulk $\mathrm{Cu} / \mathrm{Ni}$ ratio.

\section{Summary and Conclusion}

$\mathrm{Cu}_{50} \mathrm{Ni}_{50}$ nanoparticles were successfully synthesized using a modified polyol method that caused both copper and nickel compounds to be reduced simultaneously and thereby form CuNi alloy nanoparticles. CO yields with Pt/SDC catalysts equaled equilibrium $\mathrm{CO}$ yields at 650 and $700^{\circ} \mathrm{C}$. In contrast $\mathrm{CO}$ yields with $\mathrm{Cu}_{50} \mathrm{Ni}_{50} / \mathrm{SDC}$ catalysts were about $90 \%$ of the equilibrium $\mathrm{CO}$ yields at 650 and $700^{\circ} \mathrm{C}$. Catalysts with YSZ 
supports had CO yields that were approximately $55 \%$ of the CO yields obtained with catalysts having SDC supports.

The catalyst selectivity to CO was essentially $100 \%$ for the experiments performed at a hydrogen partial pressure of $1 \mathrm{kPa}$. That may have been caused in part by the $\mathrm{Cu}$ content of the catalyst surface being substantially greater than that in the bulk catalyst. The reaction results were explained using a combination of Eley-Rideal and Langmuir-Hinshelwood mechanisms that involved adsorption on the metal surface and the concentration of oxygen vacancies in the support. Finally the $\mathrm{Cu}_{50} \mathrm{Ni}_{50} / \mathrm{SDC}$ catalyst was found to be thermally stable for 48 hours at $650 / 700^{\circ} \mathrm{C}$.

Because the costs of $\mathrm{Cu}$ and $\mathrm{Ni}$ are substantially less than that of $\mathrm{Pt}$ and because the performance of the $\mathrm{Cu}_{50} \mathrm{Ni}_{50} / \mathrm{SDC}$ catalysts approached the performance of $\mathrm{Pt} / \mathrm{SDC}$ catalysts more extensive testing of supported CuNi catalysts is warranted.

\section{Conflict of Interests}

The authors declare that there is no conflict of interests regarding the publication of this paper.

\section{Acknowledgments}

Both Natural Sciences and Engineering Research Council (NSERC) and Phoenix Canada Oil Company Limited are gratefully acknowledged for their financial support. The scientific contributions provided by Dr. Marten Ternan are also acknowledged.

\section{References}

[1] T. F. Stocker, D. Qin, G.-K. Plattner et al., Climate Change 2013: The Physical Science Basis Working Group I Contribution to the Fifth Assessment Report of the Intergovernmental Panel on Climate Change, Cambridge University Press, 2013.

[2] W. Wang, S. Wang, X. Ma, and J. Gong, "Recent advances in catalytic hydrogenation of carbon dioxide," Chemical Society Reviews, vol. 40, no. 7, pp. 3703-3727, 2011.

[3] P. Vibhatavata, J.-M. Borgard, M. Tabarant, D. Bianchi, and C. Mansilla, "Chemical recycling of carbon dioxide emissions from a cement plant into dimethyl ether, a case study of an integrated process in France using a Reverse Water Gas Shift (RWGS) step," International Journal of Hydrogen Energy, vol. 38, no. 15, pp. 6397-6405, 2013.

[4] S. S. Kim, K. H. Park, and S. C. Hong, "A study of the selectivity of the reverse water-gas-shift reaction over $\mathrm{Pt} / \mathrm{TiO}_{2}$ catalysts," Fuel Processing Technology, vol. 108, pp. 47-54, 2013.

[5] S. S. Kim, H. H. Lee, and S. C. Hong, "A study on the effect of support's reducibility on the reverse water-gas shift reaction over Pt catalysts," Applied Catalysis A: General, vol. 423-424, pp. 100-107, 2012.

[6] S. S. Kim, H. H. Lee, and S. C. Hong, "The effect of the morphological characteristics of $\mathrm{TiO}_{2}$ supports on the reverse watergas shift reaction over $\mathrm{Pt} / \mathrm{TiO}_{2}$ catalysts," Applied Catalysis B: Environmental, vol. 119-120, pp. 100-108, 2012.

[7] C. Chen, C. Ruan, Y. Zhan, X. Lin, Q. Zheng, and K. Wei, "The significant role of oxygen vacancy in $\mathrm{Cu} / \mathrm{ZrO}_{2}$ catalyst for enhancing water-gas-shift performance," International Journal of Hydrogen Energy, vol. 39, no. 1, pp. 317-324, 2014.

[8] J. Papavasiliou, G. Avgouropoulos, and T. Ioannides, "Effect of dopants on the performance of $\mathrm{CuO}-\mathrm{CeO}_{2}$ catalysts in methanol steam reforming," Applied Catalysis B: Environmental, vol. 69, no. 3-4, pp. 226-234, 2007.

[9] F. S. Stone and D. Waller, " $\mathrm{Cu}-\mathrm{ZnO}$ and $\mathrm{Cu}-\mathrm{ZnO} / \mathrm{Al}_{2} \mathrm{O}_{3}$ catalysts for the reverse water-gas shift reaction. The effect of the $\mathrm{Cu} / \mathrm{Zn}$ ratio on precursor characteristics and on the activity of the derived catalysts," Topics in Catalysis, vol. 22, no. 3-4, pp. 305-318, 2003.

[10] C. S. Chen, J. H. Wu, and T. W. Lai, "Carbon dioxide hydrogenation on Cu nanoparticles," Journal of Physical Chemistry C, vol. 114, no. 35, pp. 15021-15028, 2010.

[11] C.-S. Chen, W.-H. Cheng, and S.-S. Lin, "Study of ironpromoted $\mathrm{Cu} / \mathrm{SiO}_{2}$ catalyst on high temperature reverse water gas shift reaction," Applied Catalysis A: General, vol. 257, no. 1, pp. 97-106, 2004.

[12] C.-S. Chen, W.-H. Cheng, and S.-S. Lin, "Study of reverse water gas shift reaction by TPD, TPR and $\mathrm{CO}_{2}$ hydrogenation over potassium-promoted $\mathrm{Cu} / \mathrm{SiO} 2$ catalyst," Applied Catalysis A: General, vol. 238, no. 1, pp. 55-67, 2002.

[13] C. S. Chen, J. H. Lin, J. H. You, and K. H. Yang, "Effects of potassium on $\mathrm{Ni}-\mathrm{K} / \mathrm{Al}_{2} \mathrm{O}_{3}$ catalysts in the synthesis of carbon nanofibers by catalytic hydrogenation of $\mathrm{CO}_{2}$," Journal of Physical Chemistry A, vol. 114, no. 11, pp. 3773-3781, 2010.

[14] Y. Liu and D. Liu, "Study of bimetallic $\mathrm{Cu}-\mathrm{Ni} / \gamma-\mathrm{Al}_{2} \mathrm{O}_{3}$ catalysts for carbon dioxide hydrogenation," International Journal of Hydrogen Energy, vol. 24, no. 4, pp. 351-354, 1999.

[15] M. Ismail, Model Development and Validation of Samaria Doped Ceria (SDC) Based Solid Oxide Fuel Cell Operating with Practical Fuels, Univiersity of Waterloo, 2013.

[16] G. Pekridis, K. Kalimeri, N. Kaklidis et al., "Study of the reverse water gas shift (RWGS) reaction over Pt in a solid oxide fuel cell (SOFC) operating under open and closed-circuit conditions," Catalysis Today, vol. 127, no. 1-4, pp. 337-346, 2007.

[17] T. H. Etsell and S. N. Flengas, "The electrical properties of lanthanum oxide-calcium oxide solid electrolytes," Journal of the Electrochemical Society, vol. 116, no. 6, pp. 771-778, 1969.

[18] C. Zhang, C.-J. Li, G. Zhang et al., "Ionic conductivity and its temperature dependence of atmospheric plasma-sprayed yttria stabilized zirconia electrolyte," Materials Science and Engineering B: Solid-State Materials for Advanced Technology, vol. 137, no. 1-3, pp. 24-30, 2007.

[19] W. P. Dow and T. J. Huang, "Effects of oxygen vacancy of yttriastabilized zirconia support on carbon monoxide oxidation over copper catalyst," Journal of Catalysis, vol. 147, no. 1, pp. 322-332, 1994.

[20] W.-P. Dow, Y.-P. Wang, and T.-J. Huang, "Yttria-stabilized zirconia supported copper oxide catalyst. I. Effect of oxygen vacancy of support on copper oxide reduction," Journal of Catalysis, vol. 160, no. 2, pp. 155-170, 1996.

[21] G. Avgouropoulos, M. Manzoli, F. Boccuzzi et al., "Catalytic performance and characterization of $\mathrm{Au}$ /doped-ceria catalysts for the preferential CO oxidation reaction," Journal of Catalysis, vol. 256, no. 2, pp. 237-247, 2008.

[22] H. Yahiro, K. Eguchi, and H. Arai, "Electrical properties and reducibilities of ceria-rare earth oxide systems and their application to solid oxide fuel cell," Solid State Ionics, vol. 36, no. 1-2, pp. 71-75, 1989. 
[23] R. J. Isaifan, H. A. E. Dole, E. Obeid, L. Lizarraga, E. A. Baranova, and P. Vernoux, "Catalytic CO oxidation over Pt nanoparticles prepared from the polyol reduction method supported on yttria-stabilized zirconia," The Electrochemical Society, vol. 35 , no. 28, pp. 43-57, 2011.

[24] M. Lortie, Reverse water gas shift reaction over supported CuNi nanoparticle catalysts, chapter 3 [M.S. thesis], University of Ottawa, 2014.

[25] R. J. Isaifan, S. Ntais, and E. A. Baranova, "Particle size effect on catalytic activity of carbon-supported Pt nanoparticles for complete ethylene oxidation," Applied Catalysis A: General, vol. 464-465, pp. 87-94, 2013.

[26] J. Papavasiliou, G. Avgouropoulos, and T. Ioannides, "Effect of dopants on the performance of $\mathrm{CuO}-\mathrm{CeO}_{2}$ catalysts in methanol steam reforming," Applied Catalysis B: Environmental, vol. 69, no. 3-4, pp. 226-234, 2007.

[27] A. Dauscher, L. Hilaire, F. Le Normand, W. Muller, G. Maire, and A. Vasquez, "Characterization by XPS and XAS of supported $\mathrm{Pt} / \mathrm{TiO}_{2}-\mathrm{CeO}_{2}$ catalysts," Surface and Interface Analysis, vol. 16, no. 1-12, pp. 341-346, 1990.

[28] C. M. Kalamaras, P. Panagiotopoulou, D. I. Kondarides, and A. M. Efstathiou, "Kinetic and mechanistic studies of the water-gas shift reaction on $\mathrm{Pt} / \mathrm{TiO}_{2}$ catalyst," Journal of Catalysis, vol. 264, no. 2, pp. 117-129, 2009.

[29] A. Goguet, F. C. Meunier, D. Tibiletti, J. P. Breen, and R. Burch, "Spectrokinetic investigation of reverse water-gas-shift reaction intermediates over a $\mathrm{Pt} / \mathrm{CeO}_{2}$ catalyst," Journal of Physical Chemistry B, vol. 108, no. 52, pp. 20240-20246, 2004.

[30] J. B. Peri, "A model for the surface of $\gamma$-alumina," Journal of Physical Chemistry, vol. 69, no. 1, pp. 220-230, 1965.

[31] D. A. Cadenhead and N. J. Wagner, "Low-temperature hydrogen adsorption on copper-nickel alloys," The Journal of Physical Chemistry, vol. 72, no. 8, pp. 2775-2781, 1968.

[32] E.-M. Köck, M. Kogler, T. Bielz, B. Klötzer, and S. Penner, "In situ FT-IR spectroscopic study of $\mathrm{CO}_{2}$ and $\mathrm{CO}$ adsorption on $\mathrm{Y}_{2} \mathrm{O}_{3}, \mathrm{ZrO}_{2}$, and yttria-stabilized $\mathrm{ZrO}_{2}$," Journal of Physical Chemistry C, vol. 117, no. 34, pp. 17666-17673, 2013.

[33] G. Finos, S. Collins, G. Blanco et al., "Infrared spectroscopic study of carbon dioxide adsorption on the surface of ceriumgallium mixed oxides," Catalysis Today, vol. 180, no. 1, pp. 9-18, 2012.

[34] E. Vesselli, J. Schweicher, A. Bundhoo, A. Frennet, and N. Kruse, "Catalytic $\mathrm{CO}_{2}$ hydrogenation on nickel: novel insight by chemical transient kinetics," The Journal of Physical Chemistry C, vol. 115, no. 4, pp. 1255-1260, 2011.

[35] E. Vesselli, M. Rizzi, L. de Rogatis et al., "Hydrogen-assisted transformation of $\mathrm{CO}_{2}$ on nickel: the role of formate and carbon monoxide," Journal of Physical Chemistry Letters, vol. 1, no. 1, pp. 402-406, 2010. 

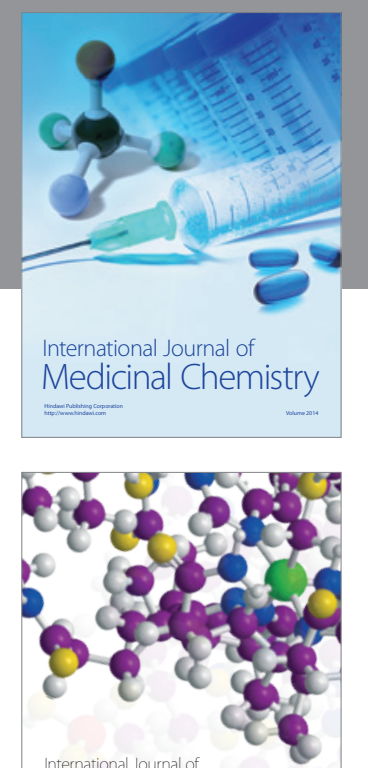

\section{Carbohydrate} Chemistry

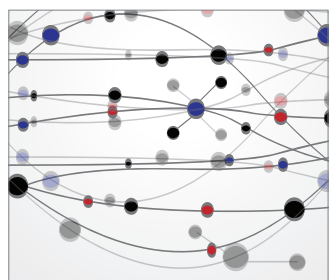

The Scientific World Journal
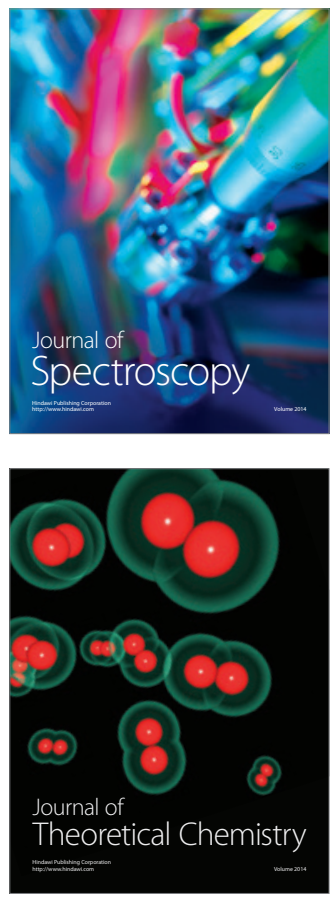
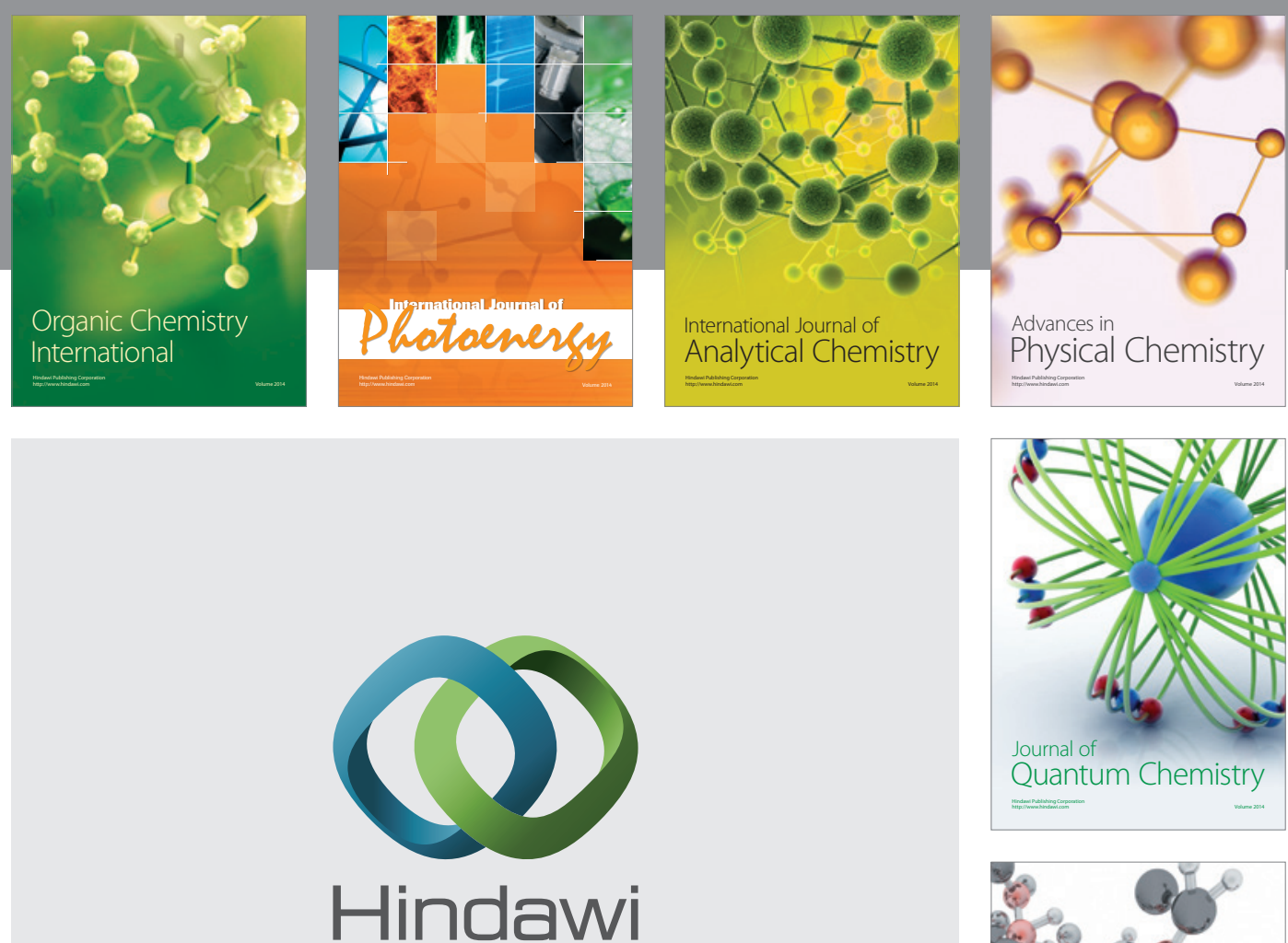

Submit your manuscripts at

http://www.hindawi.com

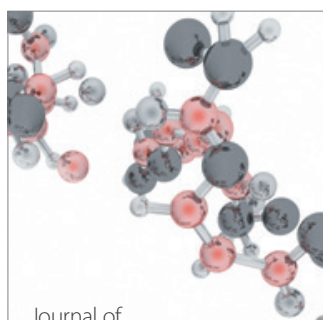

Analytical Methods

in Chemistry

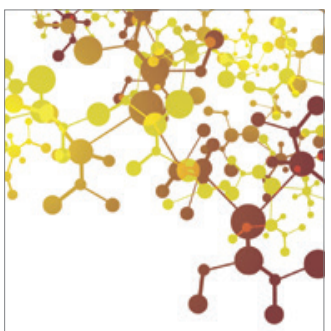

Journal of

Applied Chemistry

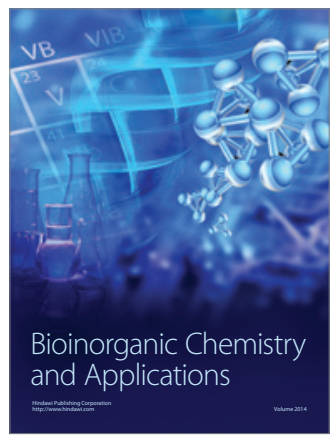

Inorganic Chemistry
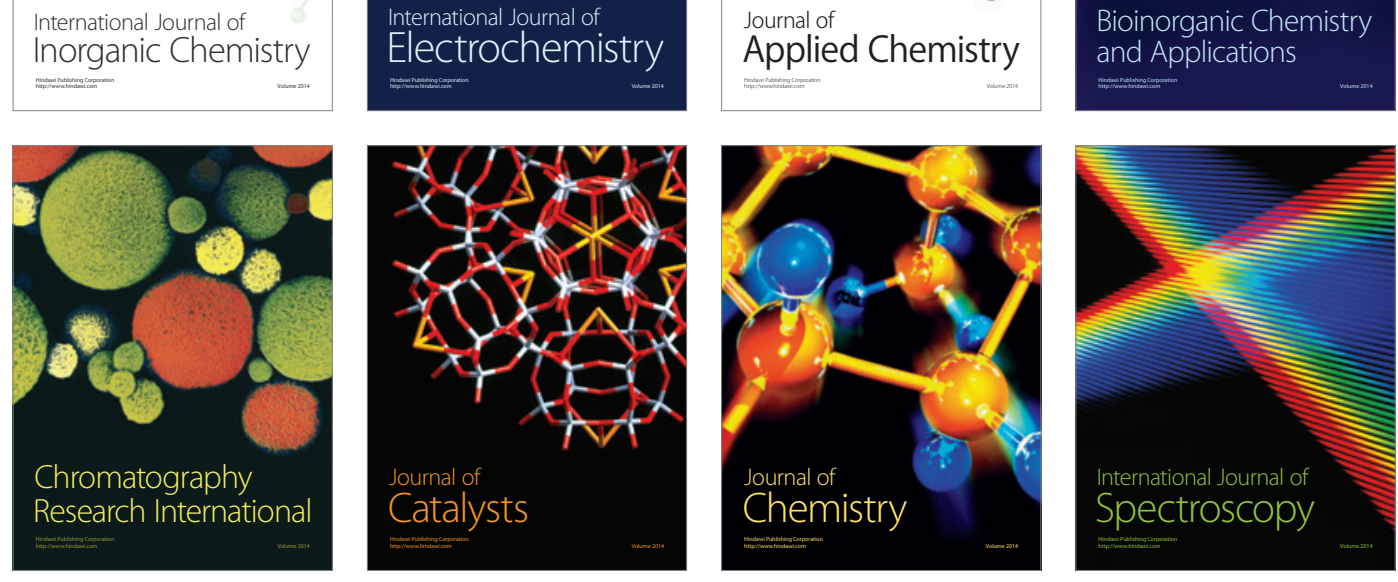